\title{
Pre-Nagssugtoqidian crustal evolution in West Greenland: geology, geochemistry and deformation of supracrustal and granitic rocks north-east of Kangaatsiaq
}

\author{
Jean-François Moyen and Gordon R.W att
}

Thearea north-east of K angaatsiaq features polyphase grey orthogneisses, supracrustal rocks and Kangaatsiaq granite exposed within a WSW -EN E-trending synform. The supracrustal rocks are comprised of garnet-bearing metapelites, layered amphibolites and layered, likewise grey biotite paragneisses. Their association and geochemical compositions are consistent with a metamorphosed volcano-sedimentary basin (containing both tholeiitic and calc-alkali lavas) and is similar to other Archaean greenstone belts. The Kangaatsiag granite forms a $15 \times 3 \mathrm{~km}$ flat, subconcordant body of deformed, pink, porphyritic granite occupying the core of the supracrustal synform, and is demonstrably intrusive into the amphibolites. The granite displays a pronounced linear fabric $(L$ or $L>S)$. The post-granite deformation developed under lower amphibolite facies conditions $\left(400 \pm 50^{\circ} \mathrm{C}\right)$, and is characterised by a regular, N E-SW -trending subhorizontal lineation and an associated irregular foliation, whose poles definea great circle; together they are indicative of highly constrictional strain. The existence of a pregranite event is attested by early isoclinal folds and a foliation within the amphibolites that is not present in the granite, and by the fact that the granite cuts earlier structures in the supracrustal rocks. This early event, preserved only in quartz-freelithologies, resulted in high-temperature fabrics being developed under upper amphibolite to granulite facies conditions.

Keywords: Archaean, deformation, supracrustal rocks, granite, N agssugtogidian

J.-F.M., D epartment of $\mathrm{G}$ eology, University of Stellenbosch, 7602 Matieland, South Africa. E-mail: jfmoyen@wanadoo.fr G.R.W., M archmyresC ottage, Breda, Alford AB33 8N Q, Aberdeen shire, U .K.

\section{Introduction and regional geology}

The northern part of the Nagssugtogidian orogen ( $\mathrm{N} N \mathrm{~N}$ ) is a domain of predominantly Archaean rocks that have been deformed and metamorphosed during Nagssugtogidian orogenic activity at c. $1.8 \mathrm{Ga}$ ( $\mathrm{H}$ ollis et al. 2006, this volume; M azur et al. 2006, this volume; Thrane \& Connelly 2006, this volume; van Gool \& Piazolo 2006, this volume). Palaeoproterozoic rocks are sparse, and apparently confined to some supracrustal belts, the most prominentonebeingtheN aternaq supracrustal belt $(\varnothing$ stergaard et al. 2002). A few small granitic-pegmatitic plugs and dykes are also related to the Pal aeoproterozoic evolu- tion. Therefore, whilethestructuresprobably reflect $N$ agssugtogidian deformation, the rocksthemselves (and their protoliths) Iargely reflect Archaean formations and evolution.

Among the Archaean units, the ubiquitous orthogneissic basement has previously been studied ( $M$ oyen et al. 2003a; Steenfelt et al. 2005); it is mostly made up of classical tonalite-trondhjemite-granodiorite (T TG ) gneisses, with minor components either related to TTG partial melting, or to the participation of peridotitic mantle in their petrogenesis. All these components are well known in the Archaean, and are probably related to the subduc- 


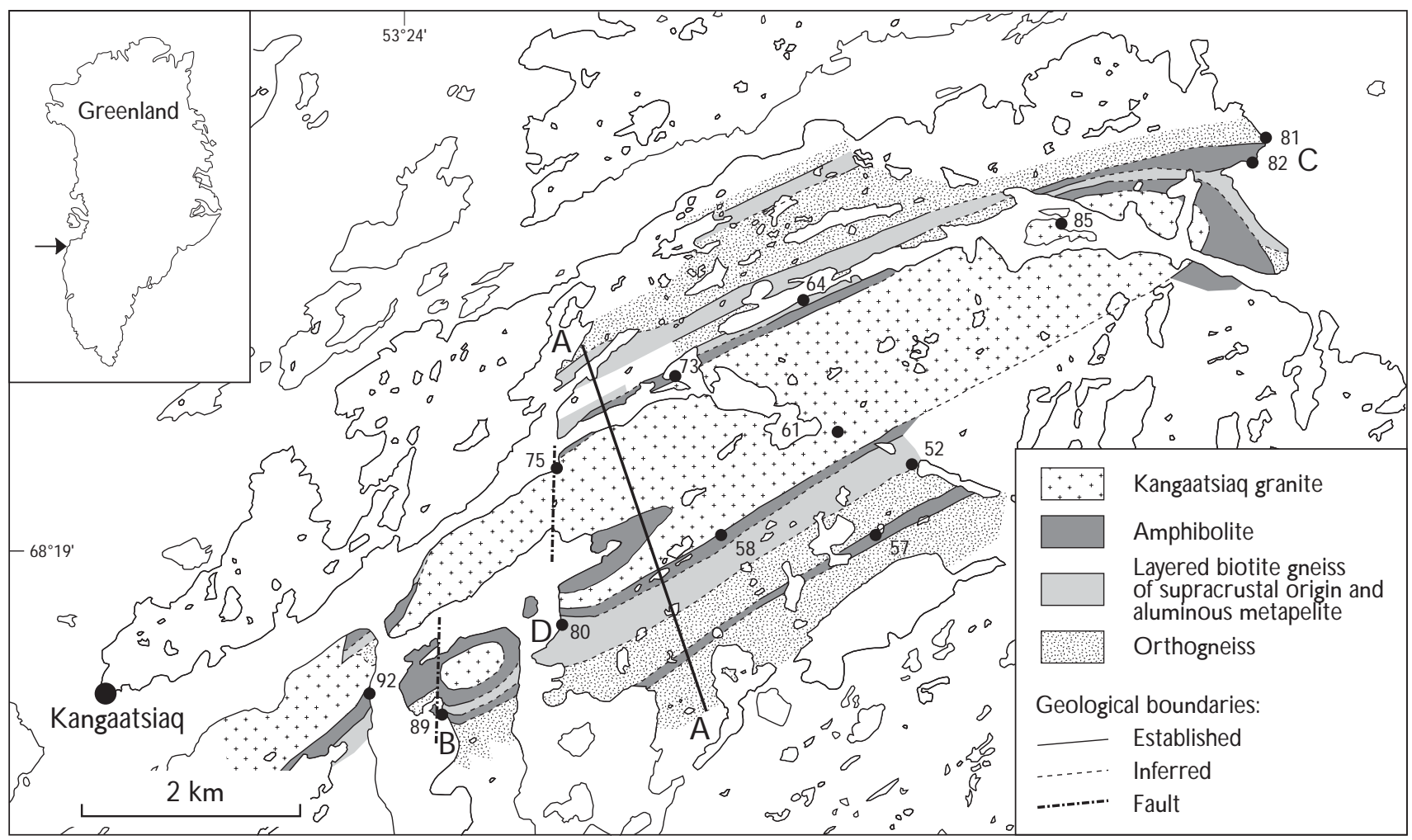

Fig. 1. Geological map of the Kangaatsiaq granite and surrounding synform, with sample localities from Table 1. Geology mostly from 2002 field work; some parts are drawn from 2001 data (J.A.M . van G ool, G.I. Alsop, S. Piazolo and S. M azur). A-A, approximate position of section on Fig. 2; B, loc. 89, see Fig. 3; C, locs 81-82, see Fig. 4; D, loc. 80, see Fig. 5.

tion of hot oceanic lithosphere in an arc setting ( $M$ artin 1986, 1994; M oyen et al. 2003b; Steenfelt et al. 2005). Several components of the gneissic basement have been dated (Kalsbeek \& N utman 1996; C onnelly \& M engel 2000; Thrane\& Connelly 2002, 2006, this volume), yielding ages in the range $2.9-2.6 \mathrm{Ga}$.

Supracrustal assemblages are common, and have been mapped in many places in the Kangaatsiaq, Aasiaat and Kangersuneq map sheet areas ( $M$ arker et al. 1995; M engel et al. 1998; $\varnothing$ stergaard et al. 2002; van Gool et al. 2002a; G arde 2004; H ollis et al. 2006, this volume). They are of two main types, either amphibolites or metasedimentary rocks, that may be either aluminous, biotite \pm muscovite \pm sillimanite \pm garnet-bearing metapelites, or quartz-rich, psammitic rocks. The age of the supracrustal rocks is, however, poorly constrained. Whilst some of them are of demonstrated Palaeoproterozoicage (c. $1.95 \mathrm{Ga}$, the $N$ aternaq supracrustal belt, $\varnothing$ stergaard et al. 2002; Thrane $\&$ Connelly 2002, 2006, this volume), others are likely to be of Archaean age, for instance anatectic metapelites in Saqqarput fjord in the southern part of the Kangaatsiaq map sheet area (Thrane \& Connelly 2006, this volume).

Lastly, small intrusions, plugs and sheets of granite and pegmatitecut across thelithologies described above. Some of them have been dated ( $K$ alsbeek \& N utman 1996; Thrane \& Connelly 2002, 2006, this volume) and yielded late Archaean ages $(2.7-2.6 \mathrm{G}$ a); it is commonly agreed that most magmatic activity in this region was related to late Archaean events, Palaeoproterozoic P-T conditions being such that anatexis was hardly achieved in the N N 0 (M azur 2002; Piazolo 2002). The very homogeneous and porphyritic Kangaatsiaq granite north-east of Kangaatsiaq, 15 by $3 \mathrm{~km}$ in outcrop size, is among the largest granitic bodies of presumed late Archaean age in the southern D isko Bugt region. Altogether, the three components outlined above are representative of the usual trilogy of Archaean terranes (W indley 1995): grey T T G gneisses; volcanic and volcano-sedimentary deposits (greenstones); and late, K -rich granites. The area east and north-east of the town of Kangaatsiaq (Fig. 1) is dominated by a synform of supracrustal rocks (mafic and felsic volcanic rocks associated with sediments), into which the Kangaatsiaq granite was emplaced. It is, therefore, a good place to study the Archaean components and local history in the N N 0 . 
Fig. 2. Schematic N N W -SSE crosssection across the K angaatsiaq granite and the surrounding synform. The laccolith shape (dashed line) is inferred, see text for details.

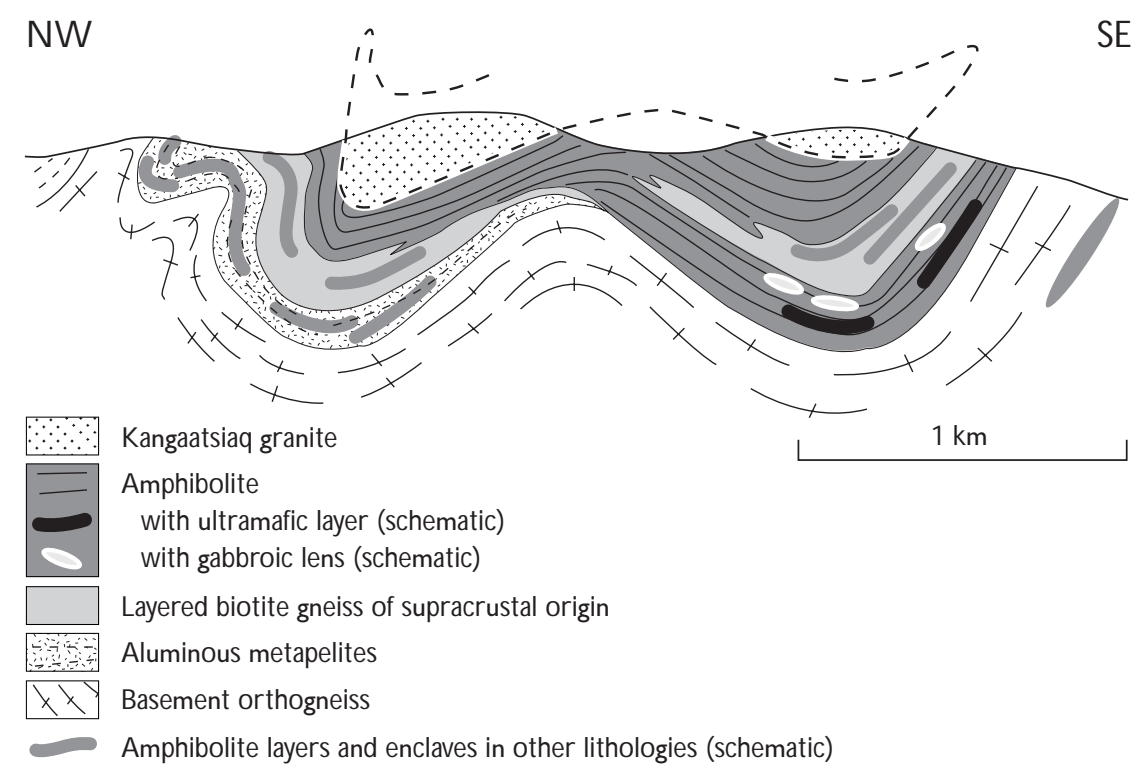

\section{Previous work}

Previous studies in the Kangaatsiaq area included reconnaissance mapping by N oe-N ygaard \& Ramberg (1961), 1:250 000 scale mapping by $H$ enderson (1969), and visits to key localities during the $D$ anish Lithosphere Centre project (M arker et al. 1995; M engel et al. 1998), asaresult of which most published ages were obtained (K alsbeek \& N utman 1996; C onnelly \& M engel 2000). M apping of the area was predominantly based on coastal exposures, while map information for large parts of the inland areas was based only on photogeological interpretation. Therefore, the Kangaatsiaq granite, which happens to crop out mostly inland and occupies the high grounds at the core of a synform, was at that time simply considered to be part of the polyphase gneissic basement.

The Geological Survey of Denmark and Greenland (GEUS) and its partners undertook more detailed mapping of the Kangaatsiaq map sheet in the summer of 2001. This included limited inland work, and the Kangaatsiaq granite was recognised for the first time as belonging to the group of the late Archaean intrusives. Its overall shape was mapped, as well as the supracrustal rocks into which it intrudes. M etasedimentary rocks in the area were also sampled, allowing for metamorphic studies (M azur 2002; Piazolo 2002).

Finally, re-evaluation of thearea in the summer of 2002 by the present authors led to the refinement of geological boundaries and the production of themap of Fig. 1. Sampling of the whole supracrustal series was also undertaken. Thin sections were cut at Université Claude-Bernard
(Lyon, France), and samples were analysed at GEUS using XRF as well as ICP-M S (Table 1). In addition, other supracrustal rocks from the samearea (obtained from A.A. $G$ arde, personal communication 2003) have been used for the interpretation presented here, as they show similar geochemical features.

\section{Map pattern}

As mentioned in the introduction, the studied area (Fig. 1 ) is mainly made up of three main components: basement orthogneisses discussed by M oyen et al. (2003a) and Steenfelt et al. (2005), a succession of supracrustal rocks which comprise a sequence of amphibolite and metasedimentary rocks described below (Figs 1, 2), and the Kangaatsiaq granite, an intrusion of pink, coarse-grained, strongly lineated ( $\mathrm{L}$ or L >Sfabric) granitewith K -feldspar phenocrysts. Thefoliated basement gneisses and the supracrustal rocks, together with early folds and structures, are refolded into a complex synform which is locally overturned, in particular on its north-western rim (see below). The granite occupies the core of the synform; it is intrusive within the top amphibolitic layer of the supracrustal sequence(Fig. 3) and isalso folded together with the supracrustal rocks. The geometry of the granite suggests that it constitutes a single sheet within the supracrustal unit, and that the original intrusion had an overall flat, laccolithlike shape (Fig. 2). We consider that the mapped contact always corresponds to the bottom of the laccolith, and that the top surface has been removed by erosion (Fig. 2). 

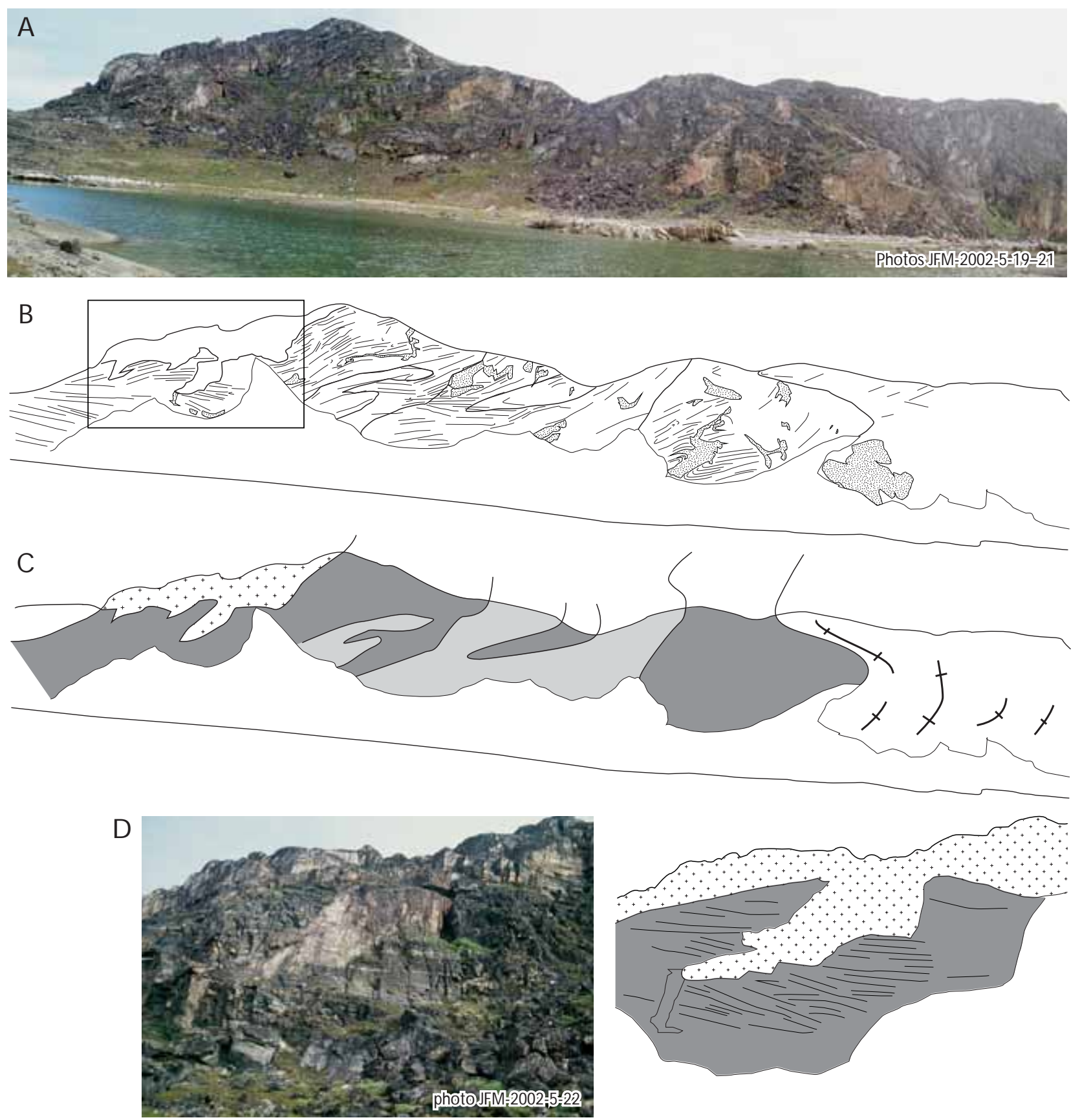

Fig. 3. Contact of the Kangaatsiaq granite and the south-western limb of the synform, loc. 89. The granite clearly intrudes the supracrustal pile, and at the same time occupies the core of the (here, slightly overturned) synform with apparently conformable relationships. A: Photomosaic of cliff face, facing east. B: Structural interpretation (stippled: pegmatites; rectangle: location of enlargement D). C: Lithological interpretation. crosses: granite; dark grey: amphibolite; light grey: layered gneiss. $\mathbf{D}:$ D etail of a small granitic apophysis which clearly cuts across the foliation of the amphibolite. 
Fig. 4. Stratigraphic succession of the K angaatsiaq synform. A: D etailed section of the overturned northern limb of the synform in its eastern extremity (locs 81-82), with sample numbers (all with prefix '485'). B: Inferred generalised logs in the north-eastern and south-western parts of the synform. Legend: see Fig. 2.

\section{A. Coastal section, locs $81-82$}

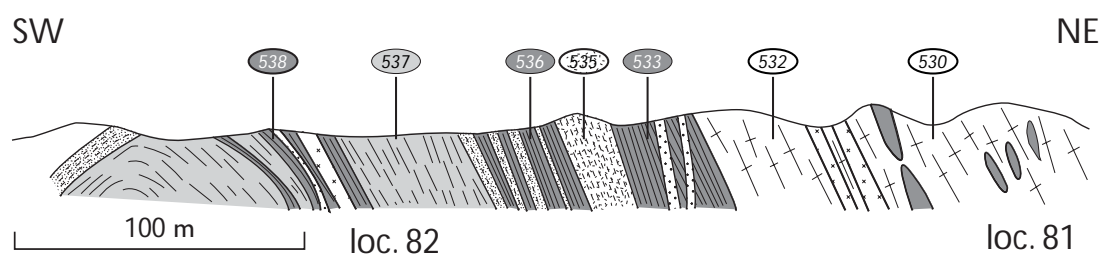

B. Generalised stratigraphic columns in the Kangaatsiaq syncline

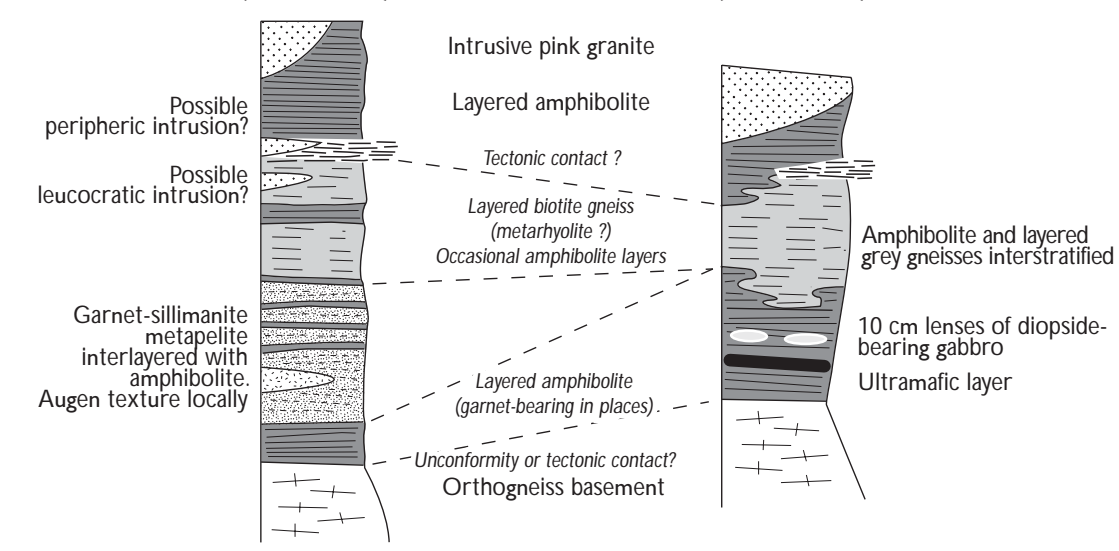

The early structures are associated with syntectonic aplites and pegmatites that cut across the amphibolite but occasionally occupy shear zones or fold hinges.

\section{The supracrustal series}

\section{Stratigraphy}

The supracrustal rocks that define the synform occur as largely discontinuous layers (Figs 2-4), that could either correspond to an original, discontinuous geometry (there fore suggesting lava flows), or simply bea result of tectonic stretching during the multiphase deformation witnessed by the area. Indeed, some of the contacts between thelithological unitsappear to betectonic(Figs4,5), suggestingthat thepresent-day 'stratigraphy' might not beoriginal. N evertheless, our mapping suggeststhat three main unitscan be recognised, allowing the following tentative stratigraphic sequence (Figs 2, 4).

1. The lowermost, c. $100 \mathrm{~m}$ thick part consists of an association of amphiboliteinterlayered with garnet-sillimanite metapelites, sometimes with augen textures. Some of the amphibolites are garnet-bearing, while others contain centimetre-sized lenses of diopside-bearing gab- bro and small ultrabasic layers (pyroxenite or serpentinite, observed in the south-western part of the synform). Thepeliticrocksseem to bemoreabundant in the northern limb and north-eastern extremity of the synform, whiletheultramafic rocksand gabbroswerefound only in its south-western part.

2. The middle part is a sequence about $100 \mathrm{~m}$ thick of layered biotite gneiss, i.e. quartzo-feldspathic gneiss with no discriminant minerals and a compositional layering at a scale of c. $10 \mathrm{~cm}$. The layered biotite gneiss is commonly interstratified with layers and lenses of amphibolite 10-100 cm thick. The contact with the lower amphibolite is gradational. As will be discussed below, the layered biotite gneiss likely represents meta-rhyolite. T he middle unit of layered biotite gneiss probably doesnot have a constant thickness; furthermore, in poor, inland outcrops, it is readily confused with basement orthogneisses. A detailed log of the lower and middle parts of the sequence as described in the foregoing was made in the overturned, north-eastern part of the synform, displaying its complex and compositenature (Fig. $3 \mathrm{~A}$, locs 81-82).

3. A horizon 50-100 m thick of fine grained, dark, layered amphiboliteforms the highest observed level. T he 

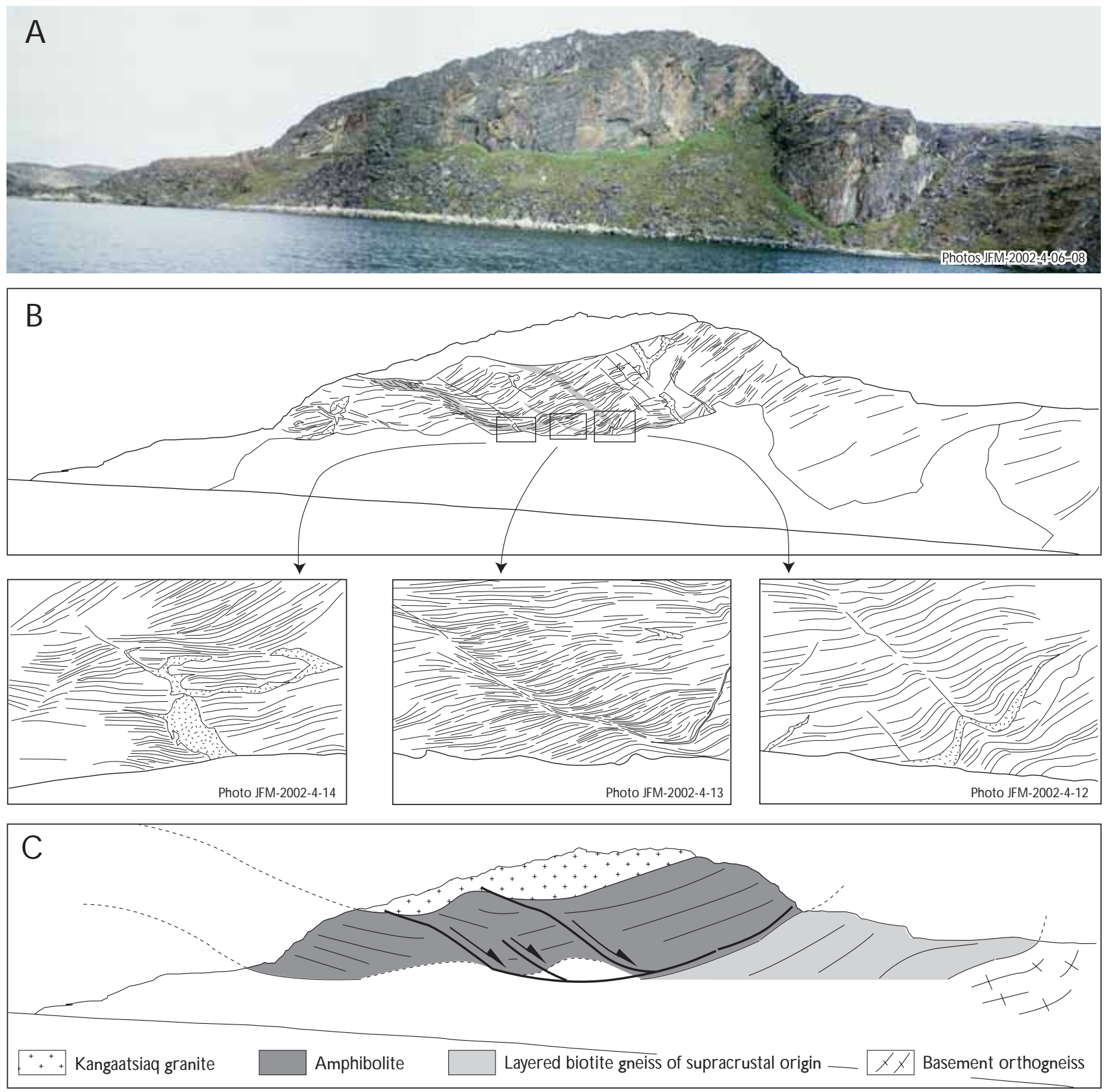

Fig. 5. Photomosaic (A) and structural interpretation (B) of the cliff face at loc. 80 (photo facing east). Stippled: pegmatites; grey: high-strain zones. Evidence for pre- to syn-granite, apparently extensional deformation is preserved in the amphibolite bodies intruded by the granite. Details of the cliff face display the apparently extensive deformation in the amphibolite. Cross-cutting pegmatites (see photo 4-12) are occasionally affected by this deformation, suggesting that it is synchronous or nearly synchronous with granite emplacement. C: Schematic relationships between the granite, the early extensional deformation, and the supracrustal pile, inspired from loc. 80. 
Fig. 6. Field and thin sections photographs of lithologies of the supracrustal series (XPL: crossed polarised light; PPL: plane polarised light). Microphotographs are c. 5 $\mathrm{mm}$ across. A1: 0 utcrop of sillimanitebearing metapelite, loc. 64 (sample 485525). $\mathrm{H}$ ammer is $80 \mathrm{~cm}$ long. A2: Thin section (XPL) of the same. B1: 0 utcrop of layered biotite gneiss interstratified with amphibolite at loc. 81 (sample 485537). Pen is $15 \mathrm{~cm}$ long. B2: Thin section (XPL) of same. C1: 0 utcrop of the top amphibolite at loc. 58 (sample 485523). Pocket knife is $10 \mathrm{~cm}$ long. $\mathbf{C 2}$ : Thin section (PPL) of same. C 3: O utcrop of gabbroic inclusions in the basal amphibolite layer at loc. 92 (sample 485541). Compass $5 \mathrm{~cm}$ wide. C4: Thin section (XPL) of clinopyroxene cluster in amphibolite. C 5 : Thin section (XPL) of sample 485540 (ultramafic layer, same locality).
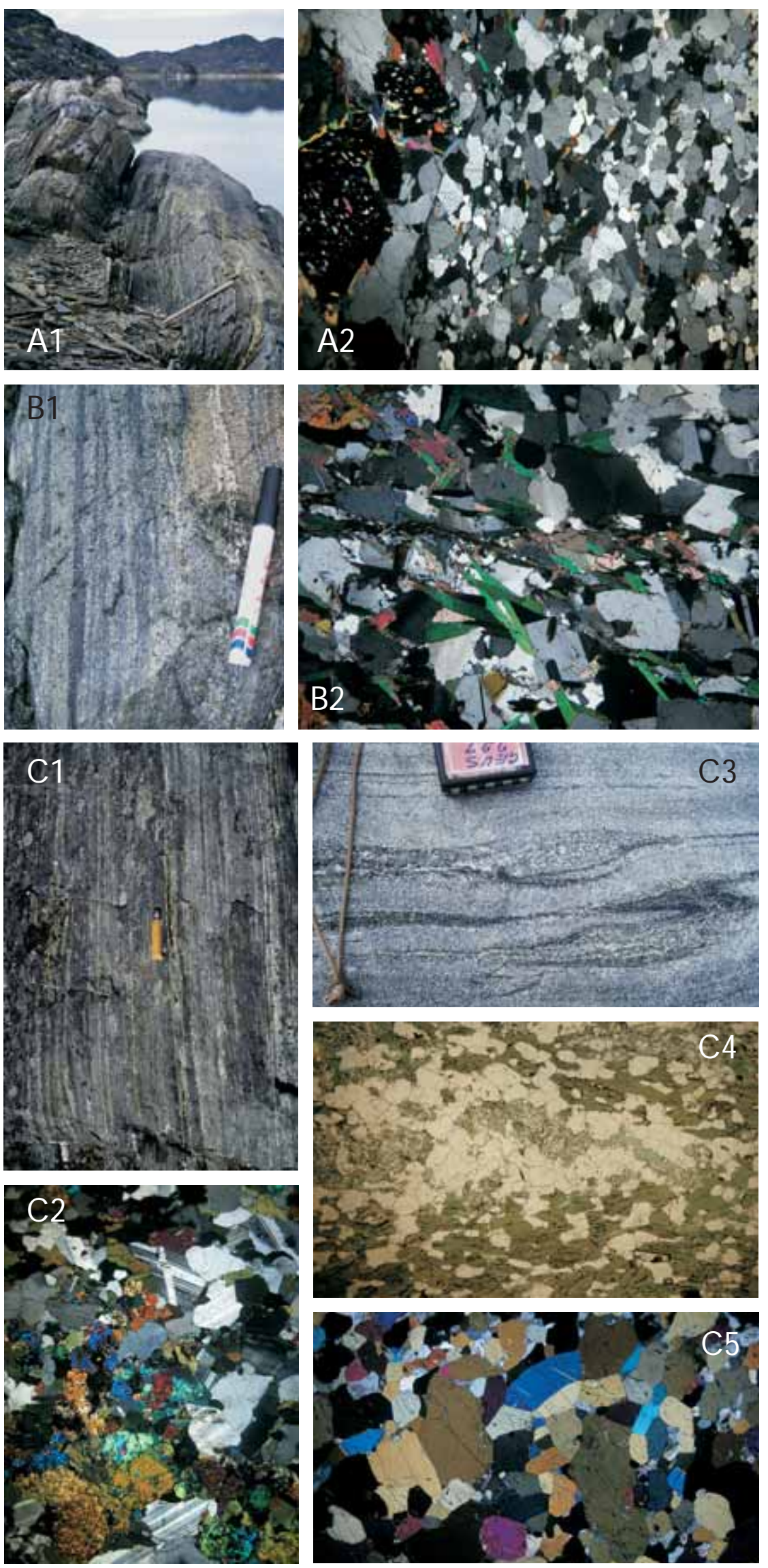


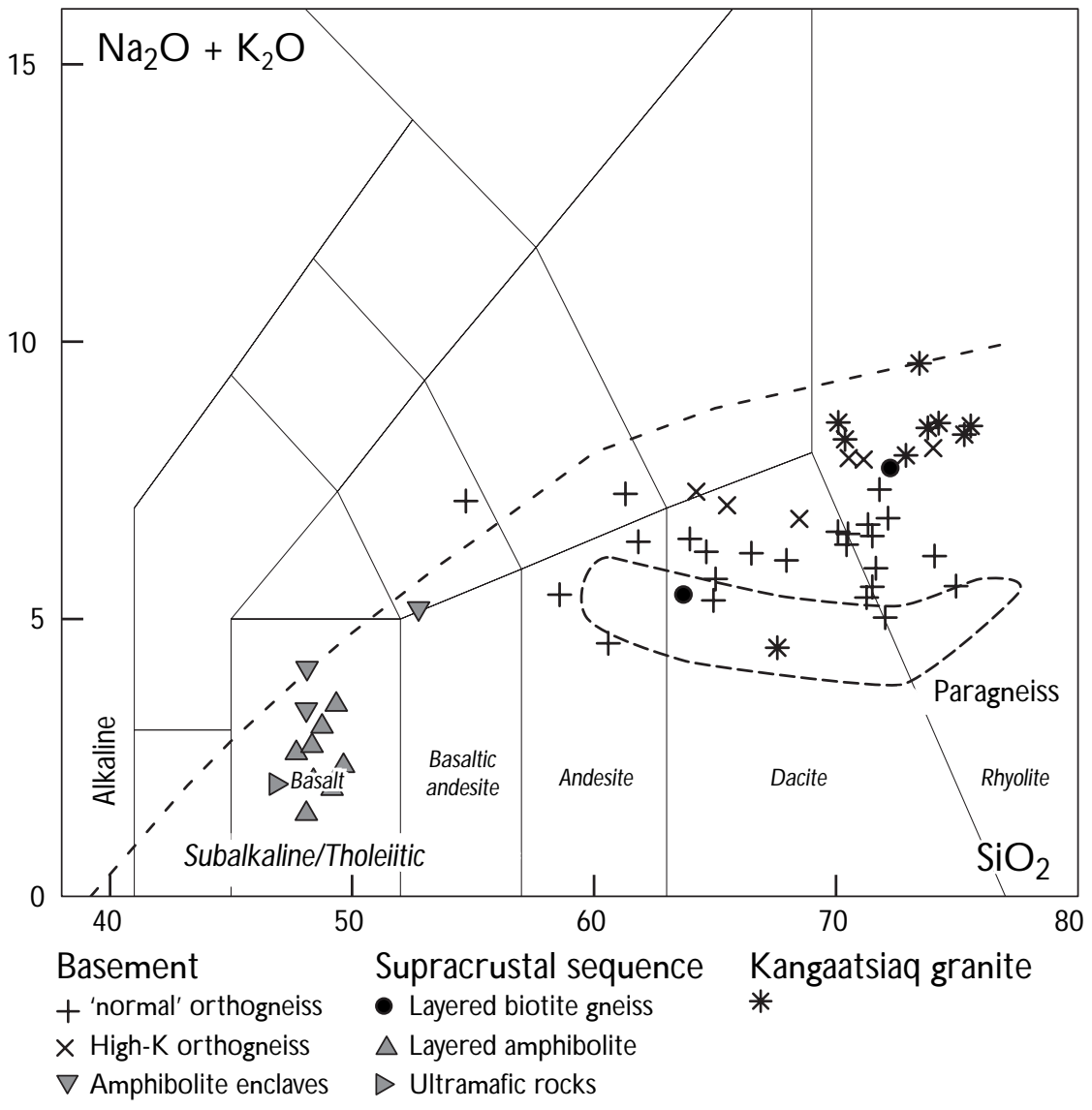

Fig. 7. Total alkali vs. silica (TAS) diagram (Le M aitre et al. 1989) for the magmatic components of the supracrustal rocks and the surrounding orthogneisses. upper boundary of this unit is not observed, since it is everywhere intruded by the granite. This top amphibolite' is continuous and can be traced all around the exposed granite contact; it is also rather homogeneous, much more so than any of the other components of the supracrustal sequence. In loc. 80 (Fig. 5), it appears to be in tectonic contact with the underlying layered biotitegneiss.

\section{Field description and petrology}

Asmentioned above, three main componentsare observed in the supracrustal succession: al uminous metapelite, layered biotite gneiss and amphibolite. Field aspects together with photographs of thin sections are presented in Fig. 6. The al uminous metapel ites occur as slaty, fine-grained (0.5-1 mm), grey to yellowish paragneisses (Fig. 6A1). Garnet or sillimanite is commonly seen in outcrop. In thin section, they display biotite, plagioclase and quartz with either sillimanite or poikiloblastic garnet (Fig. 6A2) cutting across an earlier weak foliation marked by preferred orientation of biotite flakes and elongation of plagioclase crystals.
The layered biotite gneisses appear as grey, relatively massive, fine grained $(0.5-1 \mathrm{~mm})$, finely layered rocks. They are interstratified at all scales with amphibolite(Figs $3 \mathrm{C}, 6 \mathrm{~B} 1$ ) and generally form discontinuous bodies on a 100 $\mathrm{m}$ scale. They consist of quartz, plagioclase, K-feldspar and biotite; thefoliation isdefined by the preferred orientation of biotiteand el ongation of quartzgrains(Fig. 6B2).

Theamphibolites are dark, massive rocksthat also show a strong compositional banding (Fig. 6C 1-C 2). Regardless of their mode of outcrop either as a thick continuous layer, as in the 'top amphibolite', or as discontinuous layers interstratified with other lithologies, they are very similar in visual aspect and mineralogy. They mostly consist of a fine-grained (0.5-1 mm) hornblende-plagioclase assemblage, with preferred orientation of minerals defining the foliation. Commonly, small clusters of clinopyroxene surrounded by felsic (mostly plagioclase) rims areobserved (Fig. 6C 4).

At one locality, gabbroic lenses on a scale of $5-10 \mathrm{~cm}$ have been observed within the amphibolite (loc. 92, Fig. $6 \mathrm{C} 3)$. They are medium grained $(2-5 \mathrm{~mm})$ and greenish in aspect, and composed of a clinopyroxene-plagioclase association with diffuse contacts with the neighbouring amphibolite (Fig. 6C 4). At the same locality, an ultrama- 


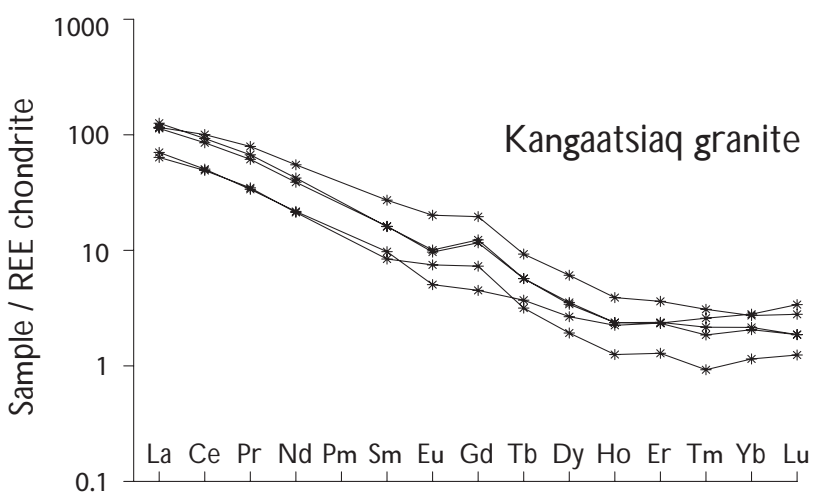

fic layer c. $0.5 \mathrm{~m}$ thick has been observed. It is slightly coarser grained (2-5 $\mathrm{mm}$ ) than the amphibolite, and solely consists of amphibole grains (Fig. 6C 5), which are optically similar to the hornblende in the surrounding amphibolite.

\section{Geochemistry and origin}

Figures 7-8 and Table 1 summarise the major and trace element (especially REE) characteristics and relationships of the threemain supracrustal components: amphibolites, metapelites and layered biotite gneisses. There is little, if any doubt of the fact that the amphibolites correspond to metamorphosed and deformed mafic igneous rocks. Elsewhere, similar field characteristics in amphibolites as those observed here have been interpreted as corresponding to transposition of former pillow lavasin high strain domains (e.g. M yers 2001). The metapelites obviously have a sedimentary origin and probably represent terrigeneous sediments. The origin of the layered biotite gneisses, however, is less obvious. They could represent either sedimentary or felsic volcanic rocks. Therefore, they are plotted on geochemical diagrams for both magmatic and sedimentary rocks (see below), allowing comparisons.

\section{0 rigin of the amphibolites}

The supracrustal amphibolites and their counterparts, enclaves in the basement orthogneisses, appear to be very similar in composition. They plot mostly as basalts in a TAS diagram (Fig. 7; Le M aître et al. 1989), and an AFM diagram (Fig. 9; I rvine \& Baragar 1971) reveals that they belong to a tholeiitic series. This, together with their spectacularly flat REE pattern at about 10 times chondritic values (Fig. 8), is consistent with the amphibolites corresponding to former M O RB basalts, possibly formed as part of an oceanic crust. M any discriminant diagrams for basaltic rocks have been proposed on geochemical grounds (e.g. Pearce 1982; Shervais 1982; M ullen 1983). H owever, some caution should be exercised when using such diagrams for the Archaean, since the existence of modern-styletectonic settings in the Archaean is not certain, and the palaeogeodynamical contexts might not be similar to those of modern settings (H amilton 1998; M cC all 2003; van Kranendonk 2003). N evertheless, in

Fig. 8. REE patterns (chondrite normalised, Boynton 1984) for the lithologies in and around the K angaatsiaq synform. 


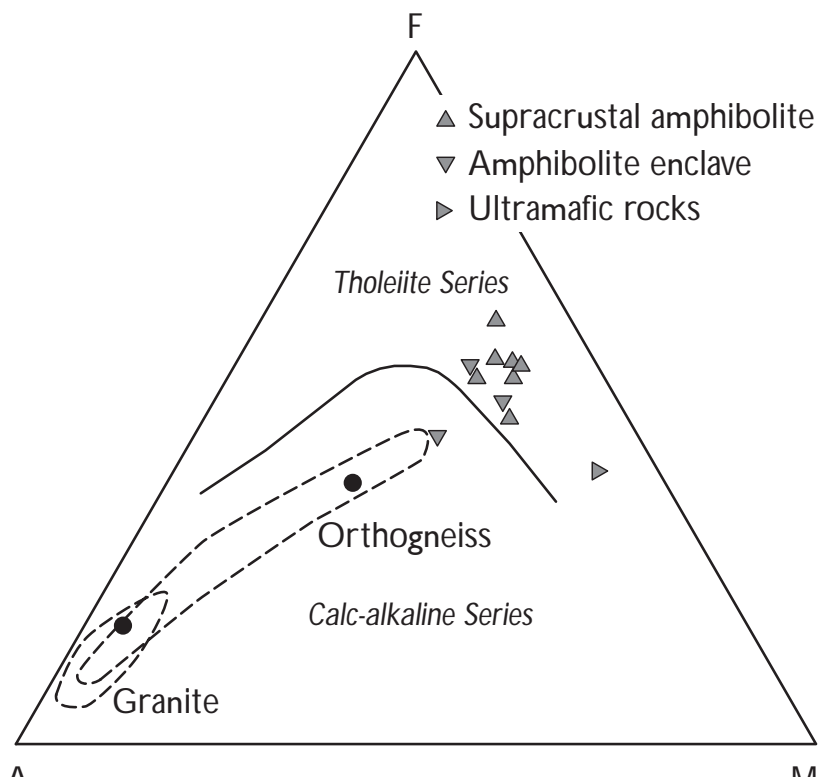

A

M

Fig. 9. AFM diagram (Irvine \& Baragar 1971) showing the tholeiitic affinity of both the supracrustal amphibolites and the enclaves in the gneisses. $\mathbf{A}, \mathrm{Na}_{2} \mathrm{O}+\mathrm{K}_{2} \mathrm{O} ; \mathbf{F}, \mathrm{FeO}_{\text {total }} ; \mathbf{M}, \mathbf{M} \mathrm{gO}$. The fields of the basement orthogneisses and the Kangaatsiaq granite are also shown for comparison.

such diagrams, the amphibolites plot either as M O RB or as rocks originated in oceanic arcs (arc tholeiites), leaving some ambiguity about their original setting.

\section{0 rigin of the aluminous metapelites}

The geochemistry of metasedimentary rocks is commonly used to discuss their source, in terms of (1) the nature of the original sediments, (2) the nature of the weathered/ eroded source material, and (3) the degree of weathering of the source (see e.g. Taylor \& M cLennan 1985; H erron 1988; Roser \& Korsch 1988; Nesbitt \& Young 1989; Bohlar et al. 2005). While several authors also use the geochemistry of sediments to discuss their geodynamical setting (Bhatia 1983; Bhatia \& C rook 1986; Roser \& Korsch 1988), some caution should be exercised when dealing with Archaean environments, as mentioned above. In terms of classification, the metasedimentary rocks from the Kangaatsiaq area plot mostly as shales or greywackes, using either of the two schemes proposed by Herron (1988). O ne of these is shown on Fig. 10A; the ambiguity and possible (chemical) confusion between thetwo groups, shales and greywackes, which are poorly separated by this diagram, has been outlined by these authors. Nevertheless, the conclusion points to relatively immature sediments which have undergonelimited transport from their source.
Thenature of the sourceitself can be discussed using major or trace elements. Roser $\&$ Korsch (1988) proposed a scheme for source determination of clastic sediments on the basis of major elements. In this instance, the studied samples straddle the P2-P3 boundary (Fig. 10B), suggesting a felsic to intermediate source. Also trace elements can be used to refine this conclusion. As pointed out by Taylor \& M CLennan (1985), some elements (high field strength elements, rare earth elements (REE), Y, Sc, Th) only undergo limited fractionation during sedimentary processes; thus, their ratios reflect the signature of their source. Plotting these elements against each other shows that the Kangaatsiaq metasedimentary rocks (Fig. 10E$\mathrm{H}$ ) have element ratios that are generally consistent with derivation from an orthogneissic source (amphibolites generally have too low trace element contents and incorrect ratios to be a possible source). The only exception is for heavy REE (Figs 8, 10G). Indeed, the relatively high $\mathrm{Yb}$ contents of the metasedimentary rocks precludes their derivation solely from a low-Yb gneissic basement, and implies that they must, at least in part, have been derived from higher-Yb rocks such as the amphibolites; this is hardly a surprise, since amphibolite occurs as enclaves intercalated within the orthogneisses. M odelling the REE contents of such a mixture shows that mixing of ortho-

\section{Facing page:}

Fig. 10. M ajor and trace element geochemistry (A-D and $\mathbf{E}-\mathbf{H}$ ) of the metasedimentary rocks (paragneisses, and layered biotite gneisses). Dotted fields show the compositions of the major regional lithologies (orthogneiss and high-K orthogneiss, M oyen et al. 2003a; Steenfelt et al. 2005; amphibolite; $\mathrm{K}$ angaatsiaq granite). A: $\mathrm{Log}\left(\mathrm{SiO}_{2} / \mathrm{Al}_{2} \mathrm{O}_{3}\right)$ vs. $\log \left(\mathrm{Fe}_{2} \mathrm{O}_{3} / \mathrm{K}_{2} \mathrm{O}\right)$, from $\mathrm{H}$ erron (1988). B : Discriminant diagrams for the metapelites, from Roser and Korsch (1988). The sources for each group areP1, mafic to intermediate volcanic rocks; $\mathbf{P 2}$, intermediate (andesitic, dacitic, occasionally rhyolitic) volcanic rocks; P3, felsic volcanic rocks; P4, evolved sediments, sandstones, etc. The discriminant functions are: $\mathbf{F} \mathbf{1}=-1.773 \mathrm{TiO}_{2}+0.607 \mathrm{Al}_{2} \mathrm{O}_{3}+0.760 \mathrm{Fe}_{2} \mathrm{O}_{3}$ $-1.500 \mathrm{MgO}+0.616 \mathrm{CaO}+0.509 \mathrm{Na}_{2} \mathrm{O}-1.224 \mathrm{~K}_{2} \mathrm{O}-9.090 ; \mathbf{F} 2$ $=0.445 \mathrm{TiO}_{2}+0.070 \mathrm{Al}_{2} \mathrm{O}_{3}-0.250 \mathrm{Fe}_{2} \mathrm{O}_{3}-1.142 \mathrm{MgO}+0.438$ $\mathrm{CaO}+1.475 \mathrm{~N} \mathrm{a}_{2} \mathrm{O}+1.426 \mathrm{~K}_{2} \mathrm{O}-6.861$. C, D : Triangular diagrams (from Nesbitt \& Young 1989). Stars: theoretical mineral compositions; il, illite; ms, muscovite; pg, plagioclase; ksp, K-feldspar; cpx clinopyroxene; hbl, hornblende; chl, chlorite; bt, biotite; sm, smectite. Dashed arrows: trends for (1) weathering and (2) K -metasomatism, after N esbitt \& Young (1989) and Bohlar et al. (2005). E, F : U vs. Th and Ti vs. Zr (log scale) diagrams, showing that the metasedimentary rocks have trace el ements ratios comparable to the gneisses, but mostly different from the amphibolites. G, H : La/Yb vs. Yb and $\mathrm{Ti} / \mathrm{Zr}$ vs. Ni (log scale) diagrams displaying the same relationships as $\mathrm{E}-\mathrm{F}$, also showing the mixing between an amphibolite-like and an orthogneiss-like source (ticks at $10 \%$ increments). 

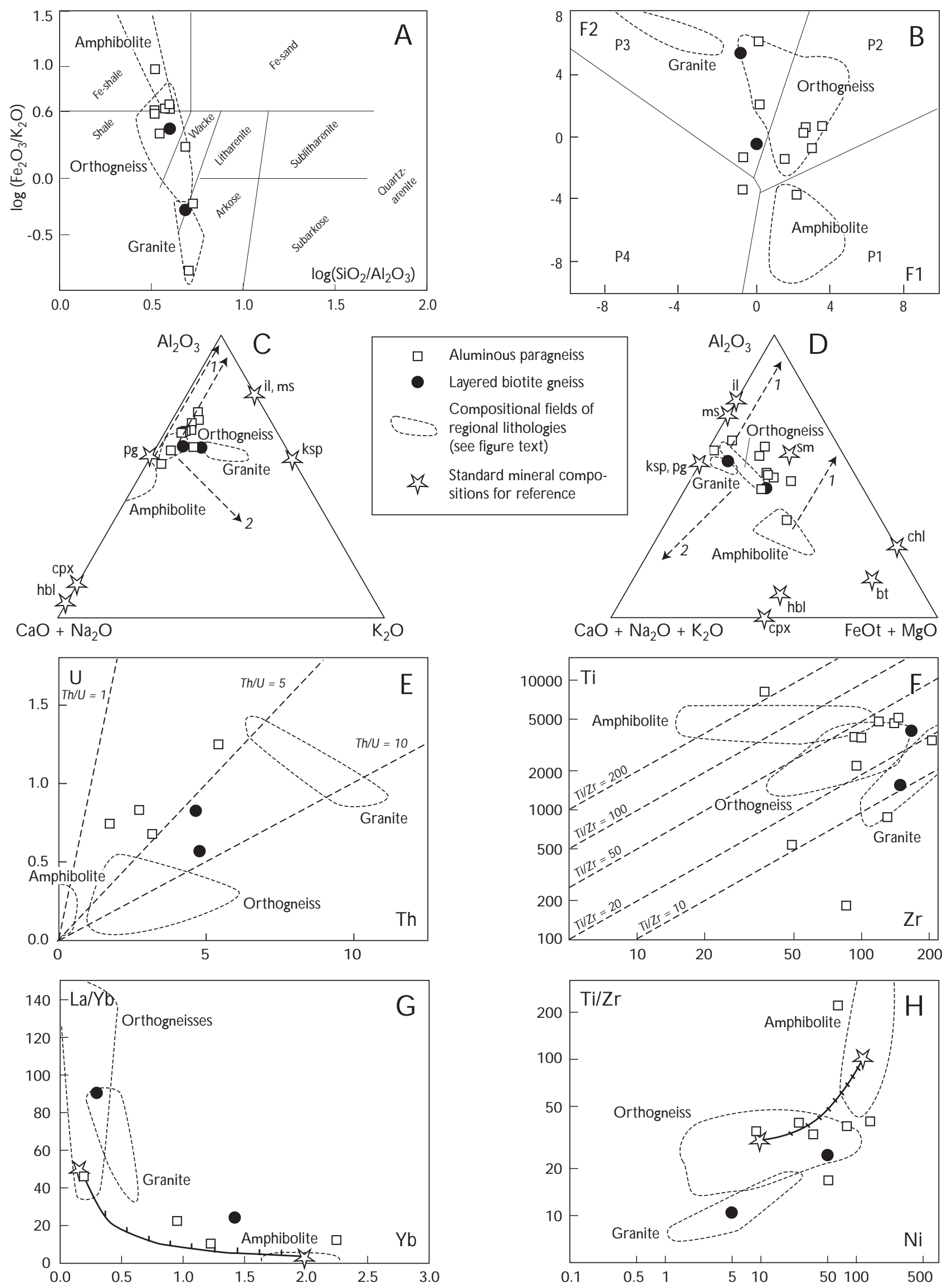


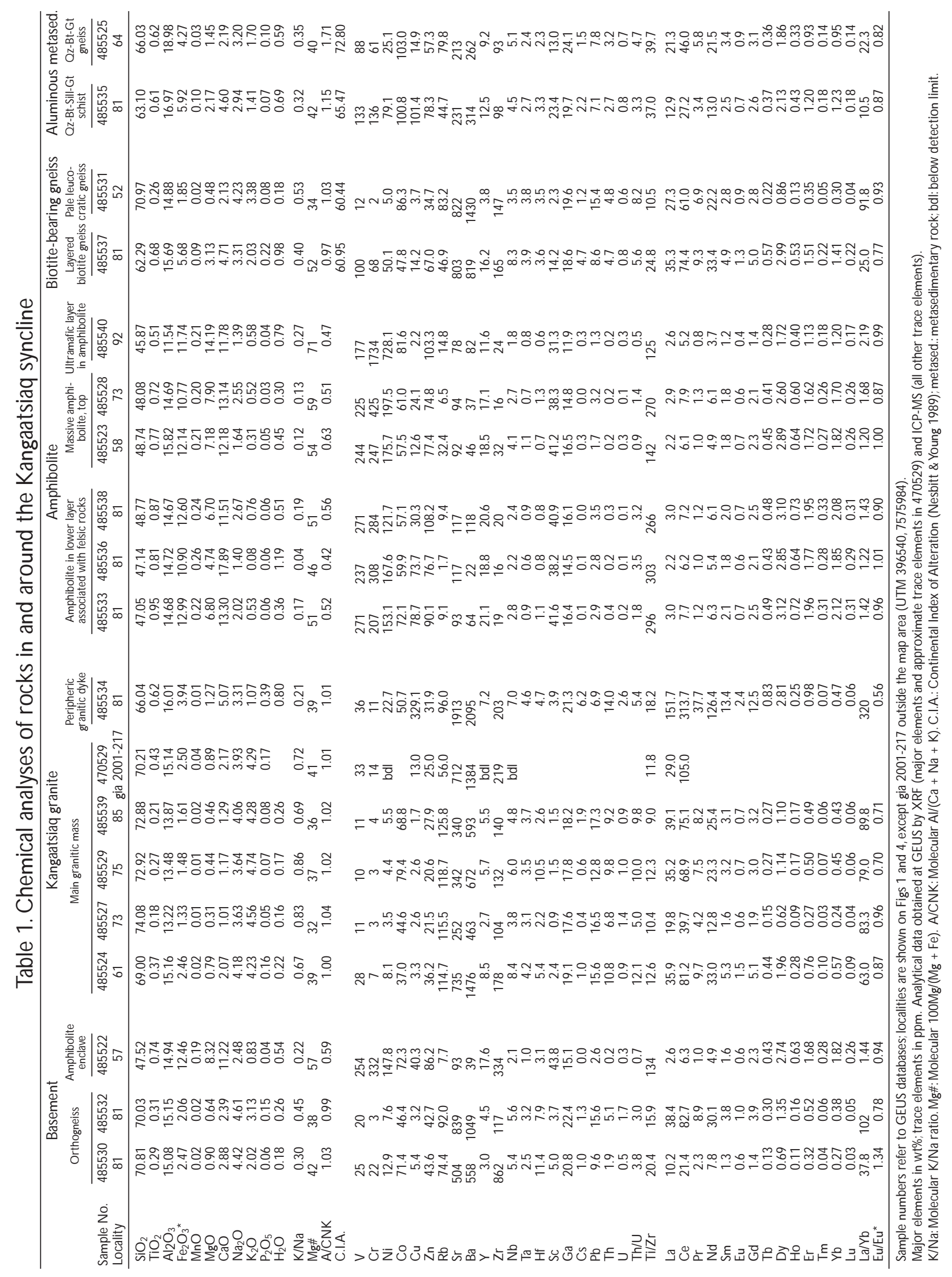


gneisses with amphibolite (Fig. 10G, H) can explain the Yb contents of the sediments; since the amphibolites are, collectively, less enriched in traceelements than thegneisses, their involvement would only have little effect on the other incompatible elements in the metasedimentary rocks. In contrast, the latter display higher $\mathrm{Ni}$ and $\mathrm{Cr}$ contents than the orthogneisses, also consistent with a contribution from amphibolite or its precursor rocks in their formation (Fig. 10H ). Finally, the degree of alteration of the source can be discussed. The metasedimentary rocks display C.I.A. values (C hemical I ndex of Alteration, N esbitt \& Young 1989) of c. 60-70 (Table 1), slightly lower than for shales or similar rocks (70-75, Taylor \& M CLennan 1985). In the triangular diagrams proposed by N esbitt $\&$ Young (1989; Fig. 10C, D ), they also depart only moderately from their protoliths, suggesting a relatively unweathered source. Very little or no evidence for secondary Kenrichment is observed.

Taking the above-mentioned limitations into account, the geoynamic setting inferred from the geochemistry gives consistent results regardless of the classification scheme used. Both the major elements classifications of Bhatia (1983) and Roser \& Korsch (1988) and the trace element systems of Bhatia \& C rook (1986) suggest an oceanic or continental island-arc setting. H owever, this only reflects the characteristics outlined above: relatively immature sediment derived from poorly weathered felsic to intermediate magmatic rocks, with a possible mafic component.

0 rigin of the layered biotite gneiss

(felsic volcanic rocks?)

The two samples analysed of the layered biotite gneisses give ambiguous geochemical signatures and can be interpreted either as sedimentary or igneous (Figs 7-10). In general, they seem to share more similarities with the granite or the orthogneisses than with any other member of the supracrustal group. In particular, Fig. 10 (C, D ) shows that if these rocks are of sedimentary origin, they are indeed very similar to their source and were derived from a largely unweathered protolith. This implies that the layered biotite gneiss can be interpreted in two ways. It may represent very immature sediment derived from a mostly unweathered protolith with a very similar bulk composition, such as a conglomerate made of pebbles of unweathered orthogneiss, in which case the banding could be a trace of the transposed pebbles. Alternatively the layered biotite gneiss represents cal c-alkali or T T G -type felsic lavas, whose composition would of course be very similar to that of their plutonic counterparts.
0 rigin of the supracrustal sequence as a whole

Based on the foregoing discussion two interpretations can be proposed for the supracrustal sequence.

1. The succession could represent a dismembered ophiolite sequenceintermingled with clastic sediments eroded from a nearby continent. The combined sequence could then beinterpreted as an accretionary prism. The likely tectonic nature of the contact between members of the sequence (see above and Figs 4, 5) supports this hypothesis.

2. The whole supracrustal pile consists of a bimodal, calcalkaline, probably subduction-related volcanic suite associated with immature terrigeneous sediments directly derived from their weathering. This is consistent with an arc situation, in which a back- or fore-arc basin is being filled with both volcanic products and detrital sediments largely derived from the weathering of these lavas. At the same time, tonalitic plutons are emplaced at depth from the same magmas. The plutonic rocks are quickly uplifted and eroded, and, besides intruding into the supracrustal pile, may in some cases al so represent the basement for subsequent volcano-detritic basin fill.

In both cases, the rocks were formed in a convergent setting, probably above or close to an active subductions margin. In general, arc- or subduction-related origins for Archaean volcanic suites are preferred by most workers (e.g. C ard 1990; Lowe 1994; W indley 1995; C hadwick et al. 1996), although theissueremains controversial ( $\mathrm{H}$ amilton 1998; M cCall 2003; van Kranendonk 2003).

\section{$\mathrm{N}$ ature and origin of the Kangaatsiaq granite}

The Kangaatsiaq graniteis pink, porphyritic, and displays a distinct rodding (Fig. 11A) showing that it has been intensely deformed (see below). W hile YZ sections (perpendicular to the main stretching direction) display a preserved magmatic texture, sections parallel to $X$ clearly show the gneissic texture of the rock. The mineralogical paragenesis is K -feldspar + quartz + sodic plagioclase + biotite, with accessory zircon, titanite, apatite and oxides.

The granite has moderate $\mathrm{K} / \mathrm{N}$ a ratios $(0.67-0.86)$, is slightly metaluminous with $A / C N K$ ratios of 1.00-1.04, and has low M g\# of 32- 41 (Table 1). $\mathrm{N} \mathrm{i}$ and $\mathrm{Cr}$ contents are also low, while Rb, Sr and Ba contents are moderate; 

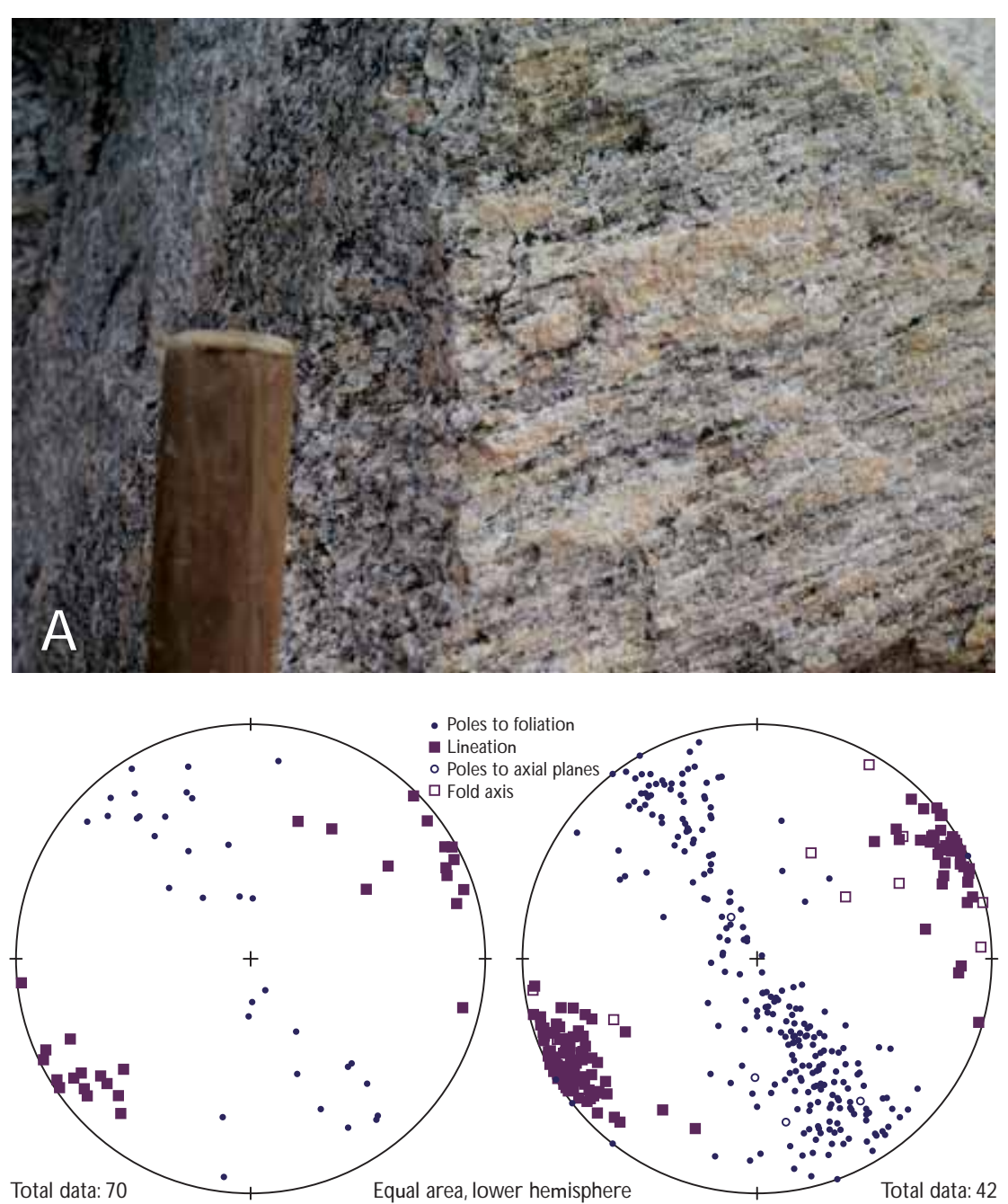

B. W ithin the granite

C. 0 utside the granite
Fig. 11. A: M acroscopic view of the Kangaatsiaq granite at loc. 75 (corresponding to sample 485529), showing strong rodding. $\mathrm{H}$ ammer shaft about $4 \mathrm{~cm}$ wide. $\mathbf{B}$, C: Stereograms of poles to foliation (circles) and lineations (squares) within and outside the granitic intrusion. The strain patterns are similar in both units and define a highly constrictional, NE-SW-trending and subhorizontal deformation. this composition corresponds to the biotite-bearing granites of M oyen et al. (2003b), which are interpreted to have been derived from partial melting of TTG gneisses. This conclusion is consistent with the highly migmatitic nature of the surrounding gneissic basement (van $\mathrm{G}$ ool et al. 2002a).

\section{Structure and deformation history}

As mentioned above, the granite displays a strong rodding and $L>S$ fabrics (Fig. 11A). The strain pattern in the granite (Fig. 11B) is consistent with highly constrictional deformation, with foliation poles plotting on a great circle, and lineations clustered near the pole of this great circle. This corresponds to subhorizontal, EN E-W SW stretching, consistent with the general orientation of the structures in Kangaatsiaq area (Fig. 1), and more general- ly with the structural grain of the region (van Gool et al. 2002a; Piazolo et al. 2004; M azur et al. 2006, this volume). T he surrounding gneissic basement and supracrustal rocks show the same strain pattern when plotted (Fig. $11 \mathrm{C}$ ), although in the field, the rocks commonly have a LS or $S>L$ fabric. This suggests that pre-existing foliations have been reoriented during the latest constrictional deformation event, leading to their present distribution. The fact that intense constriction (rather than shortening) can produce folded structures has previously been demonstrated by e.g. Leloup et al. (1995) in the Red River shear zone in Yunnan, C hina, wheretheductiledeformation in gneisses resulted in the devel opment of elongate synclinesand anticlines with axes parallel to the shear zone and the $X$-axis of deformation.

The study of deformation-related textures allows the conditions of deformation to be roughly constrained. In the granite and felsic components of the supracrustal se- 

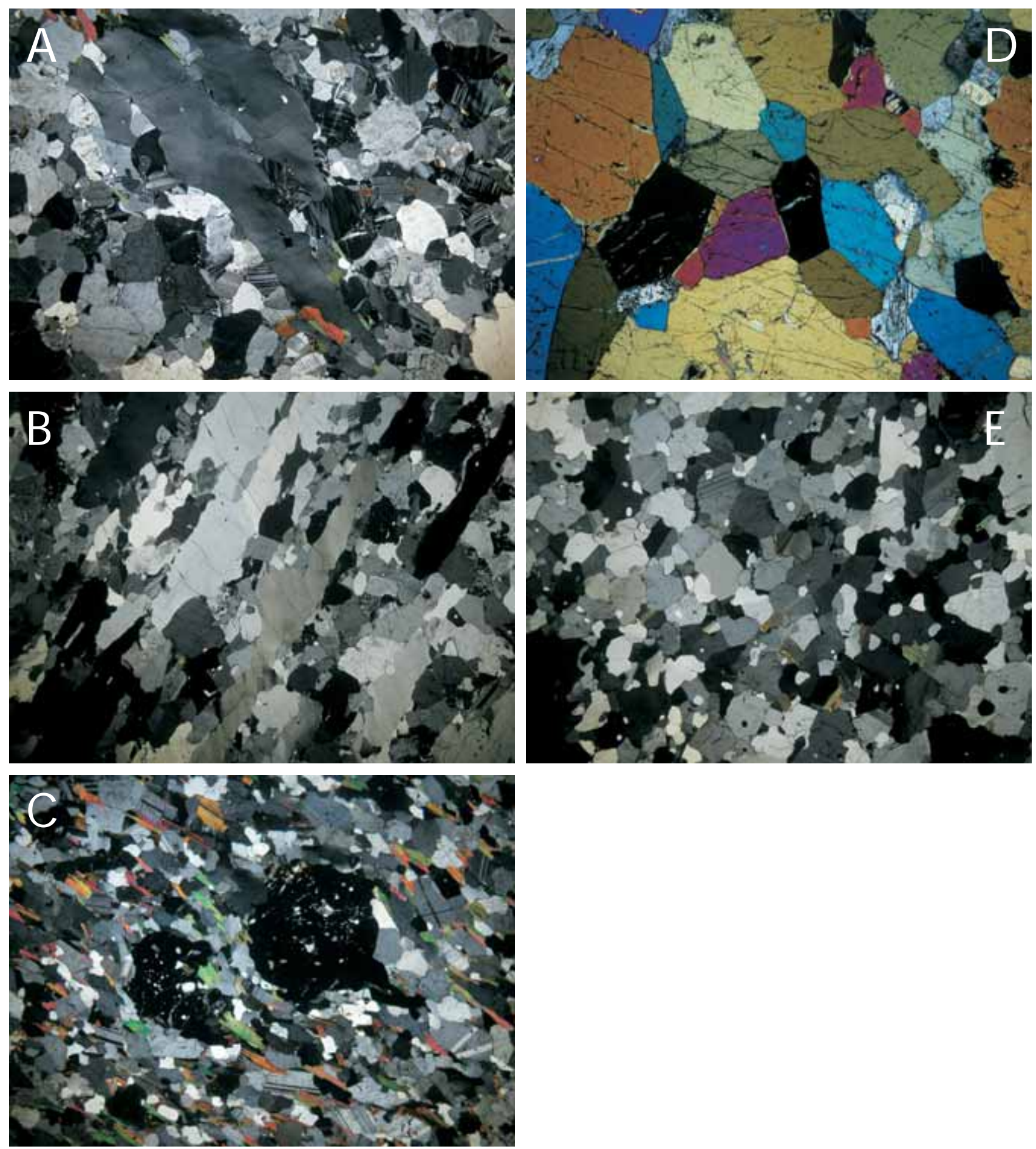

Fig. 12. D eformation textures either related to the latest, constrictional deformation (A-C) or not compatible with low- $T$ deformation (D, E). See comments in the main text. A: Q uartz ribbons in the Kangaatsiaq granite (sample 485527). B: Q uartz subgrains in felsic supracrustal gneiss (sample 485531). C: Poikiloblastic garnet in metapelite cutting across an earlier foliation (sample 485535). D, E: H igh-temperature recrystallisation with $120^{\circ}$ triple junctions in amphibolite (sample 485540) and felsic rocks (sample 485530). In E, the quartz al so shows low-temperature deformational features such as undulating extinction and quartz subgrains, indicating that this rock witnessed two successive deformation events. 


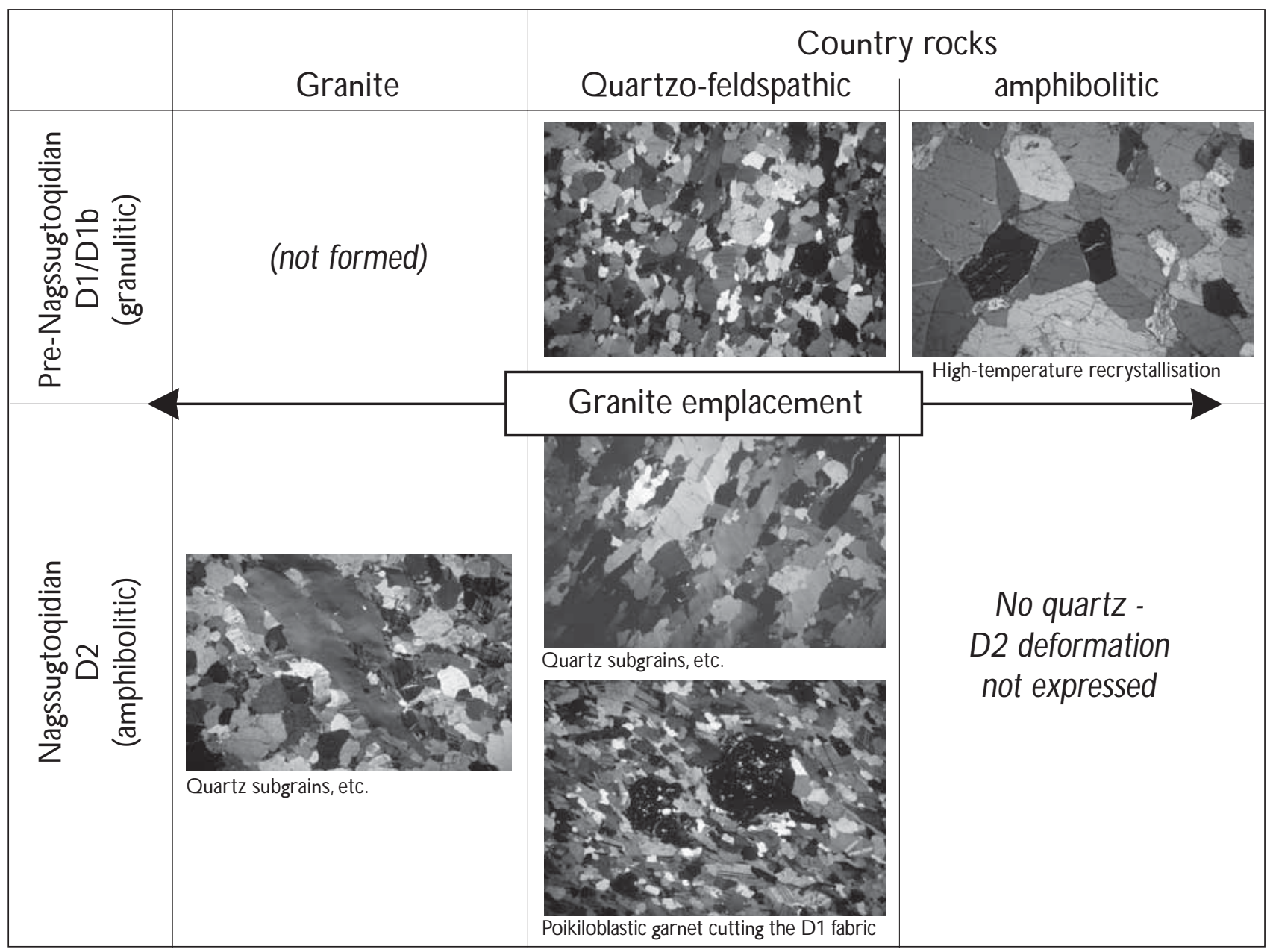

Fig. 13. Summary of the deformation history of the Kangaatsiaq synform and Kangaatsiaq granite. See comments in the main text. Photos from Fig. 12.

ries (Fig. 12A, B), the deformation led to the development of quartz subgrains and recrystallised quartz ribbons. This corresponds to deformation under lower amphibolite facies conditions $\left(400 \pm 50^{\circ} \mathrm{C}\right.$; Bouchez \& Pécher 1976; Gapais \& Barbarin 1986; Gapais 1989; Hirth \& Tullis 1992; Vernon 2000). Under these conditions, only the quartz is ductile, such that all deformation is accommodated by quartz recrystallisation or deformation. In the Al-rich lithologies, deformation-related texturesaremostly seen in the formation of poikiloblastic, syn- to post-tectonic garnets (Fig. 12C). Piazolo (2002) estimated that the chemistry of garnet in similar pelites nearby is compatible with a long duration of temperature conditions at around $500^{\circ} \mathrm{C}$, which is in broad agreement with the above estimate. W illigers et al. (2002) described the cooling history of the N N O close to our study area from Ar-Ar dating of various minerals, and likewise concluded that the cooling history of the $\mathrm{N} \mathrm{N} O$ was slow, from $400^{\circ} \mathrm{C}$ (mus- covite closure) at $1.7 \mathrm{G}$ a to $200^{\circ} \mathrm{C}$ ( $\mathrm{K}$-feldspar closure) at $1.5 \mathrm{G} \mathrm{a}$. Therefore, it can be considered that a constrictional deformation event post-dating the granite emplacement occurred during cooling to lower amphibolite facies conditions. Since this event is apparently responsible for the regional-scalestructures (M azur 2002; van Gool et al. 2002b; Piazolo et al. 2004), and is of lower Proterozoic age (W illigers et al . 2002), we propose that it corresponds essentially to the $\mathrm{N}$ agssugtogidian deformation proper.

H owever, some textures are not compatible with the above conditions. In amphibolites, high-temperature fabrics with polygonal textures and $120^{\circ}$ triple junctions are preserved (Fig. 12D). In some of the felsic supracrustal rocks or basement gneisses (but never in the granite), evidence is preserved for a similar high-temperature fabric, overprinted by later quartz recrystallisation (Fig. 12E). According to K retz (1969), Gower \& Simpson (1992), K retz (1994) and M artelat et al. (1999), such fabrics are 
likely to develop under granulite facies conditions (600$800^{\circ} \mathrm{C}$ ). T his points to the existence of one or more older (D 1?) deformation event(s). Since no evidence for this deformation is found in the granite, we suggest that it was pre-granite, and therefore likely corresponds to late Archaean deformation. P-T estimates for metapelites and metabasites in the Kangaatsiaq area by Piazolo (2002) also indicated the existence of an early metamorphic phase with P-T conditions between $650^{\circ} \mathrm{C}, 3-5 \mathrm{kbar}$ and $780^{\circ} \mathrm{C}$, $P$ unknown. This estimate is in good agreement with the textural evidence for $D 1$ deformation under lower granulite facies conditions. The pre-granite deformation is also evidenced by the early isoclinal folds, the existence of a foliation within the supracrustal rocks that does not exist in the granite, and the fact that the granite apparently cuts earlier structures (Fig. 5). At loc. 80, the granite is clearly observed cutting across the foliation and shear bands in the amphibolite; these shear bands are injected by pegmatites that might also be cut by the granite. This suggests that there were actually two pre-granite events, the first of which corresponds to the granulite facies formation of the foliation and isoclinal folds, and the second one to the pegmatite-injected shear bands. H owever, the floor of the granitic intrusion is al so apparently offset by the shear bands (Fig. 5B). Furthermore, the geometry of theshear bandsand thefoliation suggests extensional deformation; sincethe cliff facestudied hereal most corresponds to a $Y Z$ section relative to the regional constrictional de formation, this geometry is likely to correspond to the original, preserved pre-constriction geometry. Finally, the fact that the granite both cuts across, and is offset by the shear bands, suggests that the granite emplacement may actually have been syn-extension as sketched in Fig. 5C.

Altogether, the simplest possible deformation history (with the smallest number of episodes) can be summarised as follows (Fig. 13).

1. A first deformation event (D 1) under lower granulite facies conditions ( $\mathrm{c} .5 \mathrm{~kb}, 600-800^{\circ} \mathrm{C}$ ), resulted in the development of granulitic (polygonal) textures in all the existing lithologies, the formation of a main foliation, and isoclinal folding. It probably corresponds to compression of the original, likely accretionaly wedge or arc sequence.

2. This may have been followed by a second event (D Ib) of probably extensional deformation, maybe associated with (or shortly followed by) the emplacement of the granite sheet. This event, only witnessed by the shear zones cutting the $D 1$ foliation, e.g. at locality 80 , is poorly recorded and probably just represents the final stage of D 1 deformation. Assuming the granite has a late Archaean age, which is very likely in the regional context, this deformation could correspond to the later stages of the evolution of an arc or active continental margin, with strain relaxation and syn-extension granite emplacement.

3. A final event of constrictional deformation under lower amphibolite conditions (D2). D ue to the relatively low-temperature conditions, only the quartz-bearing lithologies were affected. Therefore, the granite shows strong recrystallisation, the felsic supracrustal rocks display overprinting of the $D 1 / D 1 b$ fabric by this event, and the quartz-free amphibolites were essentially unaffected by this event. The D 2 event corresponds to the purely constrictional, regional structures which have been interpreted by Piazolo et al. (2004) and M azur et al. (2006, this volume) as resulting from the indentation of the N NO by a solid, north-moving block immediately north of the Arfersiorfik shear zone (for the latter, see e.g. Sørensen et al. 2006, this volume). T his Palaeoproterozoic deformation gave the studied area its present synformal structure.

\section{Conclusions}

W hile the present-day synclinal structure of the K angaatsiaq area essentially results from $\mathrm{N} 60$ constriction related to the Palaeoproterozoic $\mathrm{N}$ agssuqtogidian deformation, the lithologies together with early preserved structures give insight into the late Archaean crustal evolution. T hebasement gneisses genetically belong to the T T G suite (M oyen et al. 2003a; Steenfelt et al. 2005), which is generally interpreted as generated by partial melting of a subducting slab (e.g. M artin 1994). Some components of the basement display implications of mantle wedge involvement in their genesis (Steenfelt et al. 2005), which is unusual in the Archaean but nevertheless consistent with an active margin setting. The supracrustal succession is composed of discontinuous layers of mafic M O RB-like or arc tholeiite lavas, and together with immature, terrigeneous shales or greywackes derived from erosion of thebasement T TG gneisses or volcanic counterparts to them, with a likely small contribution from tholeitic lavas. Part of the succession could also have been felsic rocks derived from erosion of the basement TTG gneisses or volcanic counterparts to the latter, with a likely small contribution from tholeiitic lavas. The whole series is capped by a layer $c$. $100 \mathrm{~m}$ thick of mafic volcanic rocks likewise of tholeiitic affinity. All these lithological components are in good 
agreement with either an arc-related setting, with a plutonic arc developing simultaneously with the filling of volcano-detritic basins with lavas of similar affinities and immature sediments; or with an accretionary wedge environment involving ocean floor juxtaposed together with similar sediments. In both cases, they correspond to an active subduction margin. Intense migmatisation of the basement is probably associated with the emplacement of the anatectic, likely synkinematic Kangaatsiaq granite. T his was apparently synchronous with an early, lower granulite facies (D 1/D 1b) deformation event that may have ended with strain relaxation and exhumation of the rocks from the active margin at the end of the Archaean cycle.

The supracrustal association and the sequence of events in the Kangaatsiaq area are comparable to the evolution of many Archaean greenstone belts (e.g. Card 1990; C hadwick et al. 1996; H unter et al. 1998). O $n$ the other hand, classical Archaean components such as orthochemical sediments and plume-related komatiites (Arndt 1994) or orthochemical components (Lowe 1994) are completely missing from the Kangaatsiaq area. H owever, this apparently rather uncommon absenceis known from other midto late Archaean greenstones, al so in W est G reenland (e.g. $\mathrm{G}$ arde 1997). The setting is sometimes interpreted as being arc-related (C ard 1990; Lowe 1994). In contrast, widespread melting and granite emplacement at theend of the Archaean is a very common situation, which has been described in many studies (among others, e.g. Gorman et al. 1978; Card 1990; Sylvester 1994; W indley 1995; Chadwick et al. 1996; M oyen et al. 2003b).

\section{Acknowledgements}

J.A.M. van Gool, G.I. Alsop, S. Piazolo and S. M azur visited thearea in 2001, and their work was used as a basis for the subsequent mapping. They also provided useful comments on the geology and metamorphic history of the region. A.A. Garde kindly supplied analyses of the basement gneisses; his editorial help with the figures and manuscript is also gratefully acknowledged. Reviews by A.G. Leslie and a second reviewer greatly improved the original manuscript. Linguistic corrections by R.W. Belcher were also of greatest help. C hemical analyses were performed at GEUS.

\section{References}

Arndt, N .T. 1994: Archean komatiites. In: Condie, K.C. (ed.): Archean crustal evolution. D evelopments in Precambrian Geology 11, 1144.

Bhatia, M .R. 1983: Plate tectonics and geochemical composition of sandstones. Journal of G eology 91, 611-627.

Bhatia, M .R. \& Crook, K.A.W. 1986: Trace element characteristics of graywackes and tectonic discrimination of sedimentary basins. C ontribution to M ineralogy and Petrology 92, 181-193.

Bohlar, R., Kamber, B.S., M oorbath, S., W hitehouse, M .J . \& Collerson, K.D . 2005: Chemical characterization of Earth's most ancient clastic metasediments from the I sua greenstone belt, southern West Greenland. Geochimica and C osmochimicaActa 69 (6), 1555-1573.

Bouchez, J.-L. \& Pécher, A. 1976: Plasticité du quartz et sens de cisaillement dans des quartzites du $\mathrm{G}$ rand $C$ hevauchement $C$ entral himalayen. Bulletin de la Société G éologique de France XVIII, 13771385.

Boynton, W.V. 1984: G eochemistry of the rare earth elements: meteorite studies. In: Henderson, P. (ed.): Rare earth element geochemis try, 63-114. Amsterdam: Elsevier.

Card, K.D. 1990: A review of the Superior Province of the Canadian shield, a product of Archean accretion. Precambrian Research $\mathbf{4 8}$ 99-156.

Chadwick, B., Vasudev, V.N . \& Ahmed, N. 1996: The Sandur Schsit Belt and its adjacent plutonic rocks. Implications for LateArchaean crustal evolution in Karnataka. Journal of the Geological Society of India 47, 37-57.

Connelly, J.N . \& Mengel, F.C. 2000: Evolution of Archean components in the Paleoproterozoic N agssugtogidian 0 rogen, West $G$ reenland. Geological Society of America Bulletin 112 (5), 747-763.

Gapais, D . 1989: Shear structures within deformed granites: mechanical and thermal indicators. G eology 17, 1144-1147.

Gapais, D . \& Barbarin, B. 1986: Q uartz fabric transition in a cooling syntectonic granite (H ermitagemassif, France). Tectonophysics 125 , 357-370.

Garde, A.A. 1997: Accretion and evolution of an Archaean high-grade grey gneiss - amphibolite complex: the Fiskefjord area, southern West G reenland. G eology of G reenland Survey Bulletin 177, 115 pp.

Garde, A.A. 2004: Geological map of G reenland, 1:100 000, Kangaatsiaq 68 V.1 Syd. Copenhagen: G eological Survey of Denmark and Greenland.

Gorman, B.E., Pearce, T.H . \& Birkett, T.C. 1978: O n the structure of Archean greenstone belts. Precambrian Research 6, 23-41.

Gower, R.J.W. \& Simpson, C. 1992: Phase boundary mobility in naturally deformed, high-grade quartzo-feldspathic rocks: evidence for diffusional creep. Journal of Structural Geology 14, 301-313.

H amilton, W.B. 1998: Archean magmatism and deformation were not products of plate tectonics. Precambrian R esearch 91, 143-179.

H enderson, G. 1969: Theprecambrian rocks in theEgedesminde-Chris tianshåb area, West Greenland. Rapport G rønlands G eologiskeU ndersøgelse 19, $37 \mathrm{pp}$.

H erron, M .M. 1988: G eochemical classification of terrigeneous sands 
and shales from core or log data. Journal of Sedimentary Petrology 58, 820-829.

H irth, G. \& Tullis, J. 1992: D islocation creep regimes in quartz aggre gates. Journal of Structural G eology 14, 145-159.

H ollis, J.A., Keiding, M ., Stensgaard, B.M ., van Gool, J.A.M . \& Garde, A.A. 2006: Evolution of $N$ eoarchaean supracrustal belts at the northern margin of the N orth Atlantic C raton, W est $G$ reenland. In: $G$ arde, A.A. \& K alsbeek, F. (eds): Precambrian crustal evolution and Cretaceous-Palaeogene faulting in West G reenland. G eological Survey of $D$ enmark and $G$ reenland Bulletin 11, 9-31 (this volume).

H unter, M .A., Bickle, M .J ., N isbet, E.G ., M artin, A.\& Chapman, H .J. 1998: Continental extensional setting for the Archean Belingwe $G$ reenstone Belt, Zimbabwe. Geology 26, 883-886.

Irvine, T.N . \& Baragar, W.R.A. 1971: A guide to the chemical classification of the common volcanic rocks. Canadian Journal of Earth Sciences 8, 523-548.

Kalsbeek, F. \& Nutman, A.P. 1996: Anatomy of the Early Proterozoic $\mathrm{N}$ agssugtogidian orogen, West Greenland, explored by reconnaissance SH RIM P U -Pb zircon dating. G eology 24, 515-518.

Kretz, R. 1969: O n the spatial distribution of crystals in rocks. Lithos 2, 39-66.

Kretz, R. 1994: M etamorphic crystallisation. Chichester: J. W iley and Sons.

Le M aître, R.W. et al. 1989: A classification of igneous rocks and glossary of terms, 193 pp. O xford: Blackwell.

Leloup, P.H ., Lacassin, R., Tapponnier, P., Schärer, U ., D alai, Z., Xiaohan, L., Liangshang, Z., Shaocheng, J. \& Trong Trinh, P. 1995: The Ailao Shan - Red River shear zone (Yunnan, China), Tertiary transform boundary of Indochina. Tectonophysics 251, 3-10.

Lowe, D .R. 1994: Archean greenstonerelated sedimentary rocks. In: Condie, K.C. (ed.): Archean crustal evolution. D evelopments in Pre cambrian G eology 11, 121-169.

M arker, M ., M engel, F., van Gool, J.[A.M .] \& field party 1995: Evolution of the Palaeoproterozoic N agssugtogidian orogen: D LC investigations in West G reenland. Rapport Grønlands G eologiske U ndersøgelse 165, 100-105.

M artelat, J.-E., Schulmann, K., Lardeaux, J.-M ., N icollet, C. \& Cardon, H . 1999: Granulitemicrofabrics and deformation mechanisms in southern M adagascar. J ournal of Structural G eology 21, 671687.

M artin, H. 1986: Effect of steeper Archean geothermal gradient on geochemistry of subduction-zone magmas. Geology 14, 753-756.

Martin, H . 1994: The Archean grey gneisses and the genesis of the continental crust. In: Condie, K.C. (ed.): Archean crustal evolution. D evelopments in Precambrian G eology 11, 205-259.

M azur, S. 2002: First impressions on structural evolution of the northern N agssugtogidian foreland. In: N ielsen, B.M . \& Thrane, K. (eds): W orkshop on N agssugtoqidian and Rinkian geology, West $\mathrm{G}$ reenland. D anmarks og Grønlands Geologiske U ndersøgelse Rapport 2002/9, 28-29.

M azur, S., Piazolo, S. \& Alsop, G.I. 2006: Structural analysis of the northern N agssugtogidian orogen, West G reenland: an example of complex tectonic patterns in reworked high-grade metamorphic terrains. In: Garde, A.A.\& Kalsbeek, F. (eds): Precambrian crustal evo- lution and $\mathrm{C}$ retaceous- Palaeogenefaulting in West Greenland. G eological Survey of Denmark and Greenland Bulletin 11, 163-178 (this volume).

M cCall, G.J.H . 2003: A critique of the anal ogy between Archaean and Phanerozoic tectonics based on regional mapping of the M esozoicCenozoic plate convergent zone in the $\mathrm{M}$ akran, I ran. Precambrian Research 127, 5-17.

M engel, F., van G ool, J.A.M ., K rogstad, E. \& the1997 field crew 1998: Archaean and Palaeoproter ozoic orogenic processes: D anish Lithosphere Centre studies of the Nagssugtogidian orogen, West Grenland. G eology of G reenland Survey Bulletin 180, 100-110.

M oyen, J.-F., Garde, A.A. \& Steenfelt, A. 2003a: Plain, boring orthogneisses? G eochemistry of the Archaean grey gneisses in the northern $N$ agssugtogidian belt. Workshop on Precambrian geology of central West Greenland, February 28 and M arch 1, 2003, p. 10. Copenhagen: Geological Survey of Denmark and $G$ reenland.

M oyen, J.-F., M artin, H., Jayananda, M. \& Auvray, B. 2003b: Late Archaean granites: a typology based on the D harwar Craton (India). Precambrian Research 127, 103-123.

M ullen, E.D. 1983: M nO/TiO 2/P20 5: a minor element discriminant for basaltic rocks of oceanic environments and its implications for petrogenesis. Earth and Planetary Science Letters 62, 53-62.

M yers, J.S. 2001: Protoliths of the 3.8-3.7 Ga Isua greenstone belt, West G reenland. Precambrian Research 105, 129-141.

N esbitt, H .W. \& Young, G .M . 1989: Formation and diagenesis of weathering profiles. Journal of G eology 97, 129-147.

N oe-N ygaard, A. \& Ramberg, H . 1961: G eological reconnaissance map of the country between latitudes $69^{\circ} \mathrm{N}$ and $63^{\circ} 45^{\prime} \mathrm{N}$, West Greenland, 1:500 000. Geological M ap Grønlands Geologiske Undersøgelse 1, 9 pp., 2 maps (also M eddelelser om Grønland 123(5)).

$\varnothing$ stergaard, C., G arde, A.A., Nygaard, J., Blomsterberg, J., M øller N ielsen, B., Stendal, H . \& Thomas, C.W. 2002: The Precambrian supracrustal rocks in the $\mathrm{N}$ aternaq (Lersletten) and I kamiut areas, central West Greenland. G eology of G reenland Survey Bulletin 191, 24-32.

Pearce, J A. 1982: Trace element characteristics of lavas from destructive plate boundaries. In: Thorpe, R.S. (ed.): Andesites, 525-548. Chichester: Wiley.

Piazolo, S. 2002: O verview of the metamorphic evolution of tonalitic gneisses and metasedimentary sequences from theK angaatsiaq, Lersletten and Sydostbugten area - first comparison to adjacent areas. In: Nielsen, B.M. \& Thrane, K. (eds): Workshop on N agssugtoqidian and Rinkian geology, West $G$ reenland. D anmarks og $G$ rønlands Geologiske Undersøgelse Rapport 2002/9, 32-33.

Piazolo, S., Alsop, G .I., M øller Nielsen, B. \& van Gool, J.A.M . 2004: The application of GIS to unravel patterns of deformation in high grade terrains: a case study of indentor tectonics from West Greenland. In: Alsop, G.I. \& H oldsworth, R.E. (eds): Flow processes in faults and shear zones. Geological Society Special Publication (London) 224, 63-78.

Roser, B.P. \& Korsch, R.J. 1988: Provenance signature of sandstonemudstone suite determined using discriminant function analysis of major-element data. Chemical G eology 67, 119-139.

Shervais, J.W. 1982: Ti-V plots and the petrogenesis of modern and ophiolitic lavas. Earth and Planetary Science Letters 59, 101-118. 
Sørensen, K., G lassley, W., Korstgård, J. \& Stensgaard, B.M . 2006: The N ordre Strømfjord shear zone and the Arfersiorfik quartz diorite in Arfersiorfik, the $\mathrm{N}$ agssugtogidian orogen, W est Greenland. In: G arde, A.A. \& Kalsbeek, F. (eds): Precambrian crustal evolution and $C$ retaceous- Palaeogene faulting in West G reenland. Geological Survey of D enmark and Greenland Bulletin 11, 145-161 (this volume).

Steenfelt, A., Garde, A.A. \& M oyen, J.-F. 2005: M antle wedge involvement in the petrogenesis of Archaean grey gneisses in West $G$ reenland. Lithos 79, 207-228.

Sylvester, P.J. 1994: Archean granitic plutons. In: Condie, K.C. (ed.): Archean crustal evolution. D evelopments in Precambrian Geology 11, 261-314.

Taylor, S.R. \& M cLennan, S.M . 1985: The continental crust: its composition and evolution, 312 pp. 0 xford: Blackwell.

Thrane, K.T. \& Connelly, J. 2002: Linking the N agssugtogidian orogen and the Rinkian belt: preliminary ages from the Disko Bugt region. In: N ielsen, B.M . \& Thrane, K. (eds): W orkshop on Nagssugtogidian and Rinkian geology, West Greenland. D anmarks og Grønlands G eologiske Undersøgel se R apport 2002/9, 46-48.

Thrane, K. \& Connelly, J.N . 2006: Zircon geochronology from the Kangaatsiaq- $Q$ asigiannguit region, the northern part of the 1.9$1.8 \mathrm{G}$ a N agssugtogidian orogen, West Greenland. In: Garde, A.A. $\&$ Kalsbeek, F. (eds): Precambrian crustal evolution and C retaceous-
Palaeogene faulting in West G reenland. G eological Survey of D enmark and Greenland Bulletin 11, 87-99 (this volume).

van Gool, J.A.M . \& Piazolo, S. 2006: Presentation and interpretation of structural data from the N agssugtogidian orogen using a GIS platform: general trends and features. In: Garde, A.A. \& Kalsbeek, F. (eds): Precambrian crustal evolution and Cretaceous-Palaeogene faulting in West Greenland. Geological Survey of D enmark and Greenland Bulletin 11, 125-144 (this volume).

van Gool, J.A.M . et al. 2002a: Precambrian geology of the northern $N$ agssugtogidian orogen, West Greenland: mapping in the Kangaatsiaq area. G eology of G reenland Survey Bulletin 191, 13-23.

van Gool, J.A.M ., Connelly, J.N ., M arker, M . \& Mengel, F.C. 2002b: TheN agssugtogidian orogen of West $G$ reenland: tectonic evolution and regional correlationsfrom a West $\mathrm{G}$ reenland perspective. Canadian J ournal of Earth Sciences 39, 665-686.

van Kranendonk, M.J. 2003: Archaean tectonics in 2001: an Earth odyssey. Precambrian Research 127, 1-3.

Vernon, R.H . 2000: Review of microstructural evidence of magmatic and solid-state flow. Electronic G eosciences 5(2).

W illigers, B.J.A., van Gool, J.A.M., Wijbrans, J.R., Krogstad, E.J. \& M ezger, K. 2002: Posttectonic cooling of the $\mathrm{N}$ agssugtogidian orogen and a comparison of contrasting cooling histories in Precambrian and Phanerozoic orogens. Journal of G eology 110, 503-517.

W indley, B.F. 1995: T he evolving continents, 3rd ed., 526 pp. Chester: John Wiley and Sons. 